\title{
TYRE RUBBER ADDITIVE EFFECT ON CONCRETE MIXTURE STRENGTH
}

\author{
Audrius Grinys ${ }^{1}$, Henrikas Sivilevičius ${ }^{2}$, Mindaugas Daukšys ${ }^{3}$ \\ ${ }^{1}$ Department of Building Materials, Kaunas University of Technology, Studentu g. 48, LT-51367 Kaunas, Lithuania \\ ${ }^{2}$ Department of Transport Technological Equipment, Vilnius Gediminas Technical University, \\ Plytines g. 27, LT-10105 Vilnius, Lithuania \\ ${ }^{3}$ Department of Civil Engineering Technologies, Kaunas University of Technology, \\ Studentu g. 48, LT-51367 Kaunas, Lithuania \\ E-mails: 1audrius.grinys@ktu.lt (corresponding author); ${ }^{2}$ henrikas.sivilevicius@vgtu.lt; \\ ${ }^{3}$ mindaugas.dauksys@ktu.lt \\ Received 14 Feb. 2012; accepted 02 Apr. 2012
}

\begin{abstract}
This article describes the observed and examined effect of crumb rubber on the strength (compressive, bending and splitting tensile) of concrete. The tests have shown that the change in the strength of concrete with crumb rubber waste additives can be forecasted from exponential equations. These relationships enable to foresee the regularities of strength properties when a certain amount of crumb rubber of a certain size fraction is added to concrete. The obtained exponential equations show that concrete compressive, flexural and splitting tensile strengths decrease with increasing crumbed rubber additive amount. The testing has also shown that the addition of a small amount of crumbed rubber slightly increases (7\%) the tensile splitting strength. The reason is better adhesion of the cement stone with rubber particles compared to the adhesion of sand, which was replaced by crumbed rubber. With higher content of crumbed rubber additive in the concrete, the tensile splitting strength decreases due to the significant increase of entrained air content and lower density.
\end{abstract}

Keywords: concrete strength, crumbed rubber, compressive strength, bending strength, splitting tensile strength.

\section{Introduction}

Interaction of several elements of the transport system wears down car wheel tyres and asphalt surfaces or other pavement. In time, the tyre rubber and asphalt pavement layer no longer correspond to performance parameters, as their structure requires to be changed, reinforced or improved (Sivilevičius 2011).

Old asphalt pavement can be recycled by using appropriate technologies and specialised facilities. Reclaimed asphalt pavement (RAP) features can be restored by adding a certain amount of new material (lower viscosity bitumen, mineral aggregates) and mixing it with RAP granules. Dynamics of mechanical mixing of old and new materials as well as diffusion processes determine the structure and properties of recycled hot mix asphalt (HMA) (Mučinis et al. 2009; Čygas et al. 2011; Karlsson, Isacsson 2003; Noureldin, Wood 1987; Shirodkar et al. 2011).

Non-recycled or utilised, used vehicles tyres can become a type of road waste, which could threaten the environment. Due to rapid expansion of the automobile industry in recent years, more and more waste tyre rubber got accumulated. Such rubber consist of three important components: approx. $22 \%$ of weight is synthetic fibre, $18 \%$ of weight is steel wire, and more than $60 \%$ of weight is rubber mixture, all of, which were produced from non-renewable resources (Dong et al. 2011). It was discovered that tyre rubber crumbs can be used for bituminous binders and asphalt mixtures (Zhang et al. 2010; Çelik, Atiş 2008; Lee et al. 2008; Xiao et al. 2009; Putman, Amirkhanian 2010; Xiao-qing et al. 2009). Crumbed rubber (CR) from vehicle tyres, mixed in with concrete, changes the properties of concrete (Ling 2011, 2012; Gesoğlu, Güneysi 2011; Wong, Ting 2009; Rodezno et al. 2005; Vydra et al. 2012; Muhammad et al. 2012; Najim, Hall 2012; Sukontasukkul, Tiamlon 2012). Once added to building construction materials different size fractions of CR from used tyres produce various changes in acoustic properties, thus having a noise reduction effect (Venslovas et al. 2011).

Vast amounts of used and non-biodegradable rubber tyres get accumulated in the world every year (Gaidučis et al. 2009). Recently the researchers started showing increased interest in the reuse of CR in concrete applications. Most authors (Siddique, Naik 2004; Skripkiūnas et al. 2007a, b, 2009; Stankevičius et al. 2007) who studied cement concretes modified with crumb rubber, detected deterioration in concrete strength properties when fine aggregates were replaced with CR. In different studies, authors have noticed that the size of rubber particles, their proportion in concrete and different surface texture have a significant effect on concrete strength properties. Some authors noted that reduction in concrete strength is 
greater when coarse aggregate is replaced with CR compared to the replacement of fine aggregate (Eldin, Senouci 1993, 1994; Lee et al. 1993; Siddique, Naik 2004; Topçu, Avcular 1997; Topçu, Sarıdemir 2008).

Eldin and Senouci $(1993,1994)$ determined that when coarse aggregate was replaced in full with mechanically crumbled waste rubber the compressive strength dropped by $85 \%$ whereas splitting tensile strength went down by $50 \%$. However, when fine aggregate was replaced in full with waste rubber, the authors observed lower reduction in compressive strength (65\%) and the same reduction in splitting tensile strength $(50 \%)$. Studies conducted by authors Topçu and Avcular (1997), Lee et al. (1993), Parant et al. (2007) showed greater reduction in compressive strength when coarse aggregate was replaced with CR compared to the replacement of fine aggregate.

Segre and Joekes (2000) analysed the change in compressive and bending strength of concrete with CR added at $10 \%$ of the total aggregate content. To obtain a better adhesion of cement matrix and rubber, the authors soaked rubber particles in $\mathrm{NaOH}$ solution. Scanning Electron Microscopy testing has shown that rubber particles, which were soaked in $\mathrm{NaOH}$ solution, were much more covered with cement hydrates and there were more newly formed cement crystals on the surface of soaked rubber particles compared to the particles that were not soaked in $\mathrm{NaOH}$ solution. Nevertheless, the compressive strength of concrete, where $10 \%$ of the total aggregate content was rubber particles not soaked in $\mathrm{NaOH}$, and concrete with rubber particles soaked in $\mathrm{NaOH}$ solution reduced by the same, i.e. $33 \%$, compared to control specimens. The highest bending strength was observed in concretes where waste rubber not soaked in $\mathrm{NaOH}$ solution was used. The bending strength of such concrete compared to control specimens and to concrete containing rubber soaked in $\mathrm{NaOH}$ solution was higher by $94 \%$ and $10 \%$, respectively. The reduction in compressive strength and increase in bending strength in concrete with rubber waste additives was also detected by Chinese researchers ( $\mathrm{Wu}$ et al. 2002). Whereas tests of other authors (Papakonstantinou, Tobolski 2006; Hernández-Olivares et al. 2002; Hernández-Olivares, Barluenga 2004; Barluenga, HernándezOlivares 2004; Güneyisi et al. 2004; Gesoğlu, Güneyisi 2007; Bignozzi, Sandrolini 2006; Zhu et al. 2002; Wang et al. 2005; Albano et al. 2005; Benazzouk et al. 2006; Chou et al. 2007; Taha et al. 2008; Li et al. 2004) demonstrated that both bending strength and compressive strength in concrete with $\mathrm{CR}$ was lower compared to concretes without CR.

Authors (Papakonstantinou, Tobolski 2006; Hernández-Olivares et al. 2002; Batayneh et al. 2008; Albano et al. 2005; Colom et al. 2006; Chou et al. 2007; Li et al. 2004) analysed the effect of CR on concrete's splitting tensile strength. Comprehensive analysis of literature has revealed that tensile strength reduces with the addition of CR. Splitting tensile strength of concrete reduces the more the higher amount of CR is added.

Most authors (Papakonstantinou, Tobolski 2006; Güneyisi et al. 2004; Albano et al. 2005; Benazzouk et al. 2006), who analysed concrete strength, noticed that compressive strength reduces much more than bending and tensile strengths in concretes modified by CR. Benazzouk et al. (2006) explained lower reduction in bending and tensile strengths in concrete containing CR by rougher rubber particle surface texture compared to the replaced fine and coarse aggregates (sand, gravel), which have smooth surface and spherical shape. Due to their rough surface, rubber particles bind with cement stone better and, therefore, resist tensile stress more effectively.

The authors explain the reduction in concrete strength properties as follows:

1. Rubber particles have lower strength than concrete matrix around them, and thus, when force is applied, the cracks first of all appear in the contact zone of rubber and concrete matrix (Papakonstantinou, Tobolski 2006; Güneyisi et al. 2004; Khatib, Bayomy 1999; Eldin, Senouci 1993, 1994; Lee et al. 1993; Topçu, Avular 1997). Cracks gradually propagate under load until concrete crumbles. Such rubber performance discrepancy makes rubber particles similar to voids in concrete (Bignozzi, Sandrolini 2006; Benazzouk et al. 2006; Eldin, Senouci 1994).

2. When aggregates of bigger density and strength are replaced with less dense CR, the compressive strength decreases because properties of the aggregate have a big effect on compressive strength of concrete (Papakonstantinou, Tobolski 2006; Batayneh et al. 2008; Eldin, Senouci 1994).

3. A decrease in mechanical properties of concrete containing CR is also explained by low adhesion between rubber particles and cement matrix (Segre, Joekes 2000; Güneyisi et al. 2004; Siddique, Naik 2004; Li et al. 2004). To increase the adhesion, some authors recommended soaking waste rubber in $\mathrm{NaOH}$ solution (Segre, Joekes 2000; Güneyisi et al. 2004; Siddique, Naik 2004; Li et al. 2004; Papakonstantinou, Tobolski 2006); however authors (Hernández-Olivares et al. 2002; Benazzouk et al. 2006; Papakonstantinou, Tobolski et al. 2006) observed strong adhesion in the contact zone of rubber particles and cement matrix.

\section{Used materials}

Portland cement CEM I $42.5 \mathrm{~N}$ manufactured by $A B A k$ menés cementas was used as a binding material. $0 / 4$ fraction sand from Kvesai quarry was used as a fine aggregate. 4/16 fraction gravel macadam from Kvesai quarry was used as a coarse aggregate.

Waste automotive tyres were mechanically shredded into separate fractions of $0 / 1,1 / 2$ and $2 / 3$ and used as a crumb rubber waste additive. Waste tyre shredding equipment belongs to UAB Metaloidas, Šiauliai. Sand was replaced by $\mathrm{CR}$ at $5 \%, 10 \%, 20 \%$ and $30 \%$ of the total aggregate amount. Superplasticizer Muraplast FK63,30 based on polycarboxylic resins was used in experimental testing.

To determine the influence of CR on the compressive strength, bending strength (Fig. 1) and splitting tensile strength properties of hardened concrete, different mixtures were made under laboratory conditions: control 
Table 1. Compositions of concrete mixtures

\begin{tabular}{|c|c|c|c|c|c|c|c|c|}
\hline \multirow[b]{2}{*}{ Notation } & \multirow{2}{*}{$\begin{array}{l}\text { CR frac- } \\
\text { tion, mm }\end{array}$} & \multicolumn{7}{|c|}{ Materials content for $1 \mathrm{~m}^{3}$ of concrete mixture } \\
\hline & & $\begin{array}{c}\text { Volume of } \\
\text { R, \% }\end{array}$ & $\begin{array}{l}\mathrm{R} \text { amount, } \\
\mathrm{kg}\end{array}$ & Cement, kg & $\begin{array}{l}\text { Sand } 0 / 4, \\
\mathrm{~kg}\end{array}$ & $\begin{array}{l}\text { Gravel mac- } \\
\text { adam } 4 / 16, \mathrm{~kg}\end{array}$ & $\begin{array}{c}\text { Chemical } \\
\text { additive, kg }\end{array}$ & Water, $l$ \\
\hline NR & - & - & - & 451 & 875 & 949 & 2.255 & 160 \\
\hline R 0/1_5 & \multirow{4}{*}{$0 / 1$} & 5 & 35.14 & \multirow{4}{*}{451} & 784 & \multirow{4}{*}{949} & \multirow{4}{*}{2.255} & \multirow{4}{*}{160} \\
\hline R 0/1_10 & & 10 & 70.28 & & 693 & & & \\
\hline R 0/1_20 & & 20 & 140.55 & & 510 & & & \\
\hline R 0/1_30 & & 30 & 210.83 & & 328 & & & \\
\hline $\mathrm{R} 1 / 2 \_5$ & \multirow{4}{*}{$1 / 2$} & 5 & 35.14 & \multirow{4}{*}{451} & 784 & \multirow{4}{*}{949} & \multirow{4}{*}{2.255} & \multirow{4}{*}{160} \\
\hline $\mathrm{R} 1 / 2 \_10$ & & 10 & 70.28 & & 693 & & & \\
\hline $\mathrm{R} 1 / 2 \_20$ & & 20 & 140.55 & & 510 & & & \\
\hline $\mathrm{R} 1 / 230$ & & 30 & 210.83 & & 328 & & & \\
\hline $\mathrm{R} 2 / 3 \_5$ & \multirow{4}{*}{$2 / 3$} & 5 & 35.14 & \multirow{4}{*}{451} & 784 & \multirow{4}{*}{949} & \multirow{4}{*}{2.255} & \multirow{4}{*}{160} \\
\hline $\mathrm{R} 2 / 3 \_10$ & & 10 & 70.28 & & 693 & & & \\
\hline $\mathrm{R} 2 / 320$ & & 20 & 140.55 & & 510 & & & \\
\hline $\mathrm{R} 2 / 3 \_30^{*}$ & & 30 & 210.83 & & 328 & & & \\
\hline
\end{tabular}

* none technological mixture

mixture - non rubberised (NR) concrete and concrete with different size and amount of CR. Three different types of waste rubbers granules sized between the ranges of $0-1,1-2$ and $2-3 \mathrm{~mm}$ were used as waste rubber aggregates. Proportions of the concrete mixtures are presented in Table 1.

As regards concrete mixture it was found that using $2 / 3$ fraction of $30 \%$ of CR homogeneity of concrete was lost due to segregation of aggregates. For this reason, the concrete mixture notated R 2/3 30 was not used in further experiments.

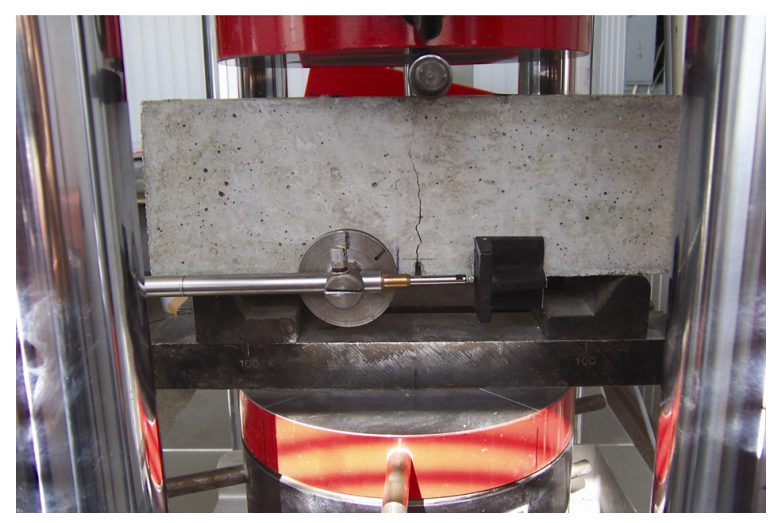

Fig. 1. Testing of concrete bending strength

\section{Experimental procedure}

\subsection{The effect of crumbed rubber size fraction and amount on compressive strength of concrete}

Fig. 2 illustrates the change in compressive strength of concrete modified with different amounts of CR. The tests revealed that the amount of CR and fraction size had a significant effect on the compressive strength of concrete. The average compressive strength of specimens without $\mathrm{CR}$ is $64.3 \mathrm{MPa}$ (standard deviation $\sigma=2.5 \mathrm{MPa}$ ). The addition of $\mathrm{CR}$ caused the compressive strength to decrease. When CR additive was added at $5 \%$ of the total aggregate amount, the compressive strength of concrete decreased to $46.2 \mathrm{MPa}(\sigma=3.6 \mathrm{MPa})$. According to tests, compressive strength reduced with smaller fraction size of CR additive (Fig. 2). These tests showed that when the amount of $\mathrm{CR}$ was increased to $10 \%$ of the total aggregate amount, the compressive strength decreased to $33.8 \mathrm{MPa}$ $(\sigma=3.1 \mathrm{MPa})$. In concretes with $10 \%$ of CR the compressive strength decreased very similarly as in concretes with $5 \% \mathrm{CR}$. When the size fraction of rubber particles was smaller, the compressive strength decreased more. In this case, the compressive strength values were noticed to go down to $22.9(\sigma=3.4 \mathrm{MPa}), 22.2(\sigma=4.7 \mathrm{MPa})$ and 14.2 $(\sigma=2.6 \mathrm{MPa}) \mathrm{MPa}$ depending on the CR size fraction. According to the data of Fig. 2, it may be concluded that compared to the control specimens, the highest decrease in the compressive strength of concrete was obtained when the highest amount of CR was used (at 30\% of the total aggregate amount). Fig. 2 shows that $\mathrm{CR}$ of $1 / 2$ size fraction added at $30 \%$, decreased the compressive strength by $84 \%$, and $0 / 1 \mathrm{fr}$. additive decreased the compressive strength by $85 \%$.

Fig. 3 illustrates the standard deviation in the compressive strength of concrete. The standard deviation of compressive strength ranged from $1.2 \mathrm{MPa}$, when $0 / 1 \mathrm{fr}$. CR was added at $30 \%$ of the total aggregate amount, to 4.7 $\mathrm{MPa}$, when respectively $1 / 2 \mathrm{fr}$. and $20 \% \mathrm{CR}$ was used. It may be stated that $\mathrm{CR}$ additive has no effect on the standard deviation of the compressive strength of concrete. Low standard deviation values obtained in testing confirmed insignificant variation of results, thus proving the reliability of obtained results.

Decreased compressive strength resulting from modification of concrete with CR can be explained by several reasons:

1. Rubber particles are more elastic and weaker compared to the surrounding cement matrix, therefore, the formation of cracks begin in the contact zone of rubber and cement matrix (Khatib, Bayomy 1999; Eldin, Senouci 1993, 1994; Lee et al. 1993; Topçu, Avcular 1997). When load is applied, the cracks gradually propagate and concrete crumbles. Such rubber performance discrepancy makes rubber particles act similarly to voids in concrete (Eldin, Senouci 1994). 


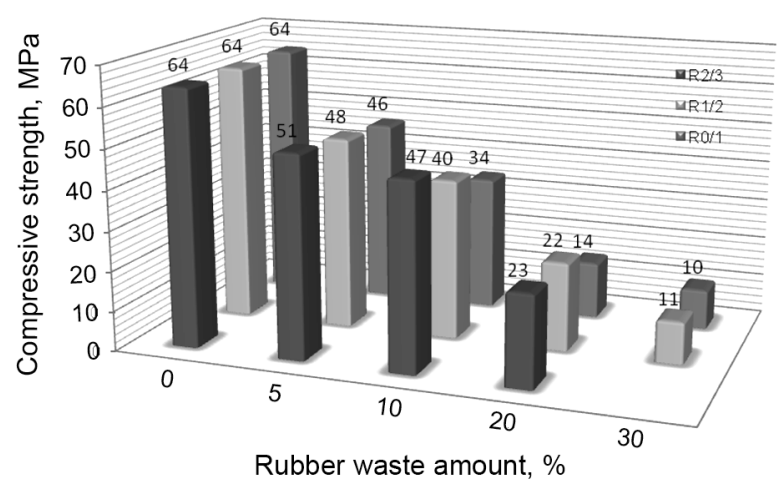

Fig. 2. The change in the compressive strength of concrete with CR of different amount and size fraction

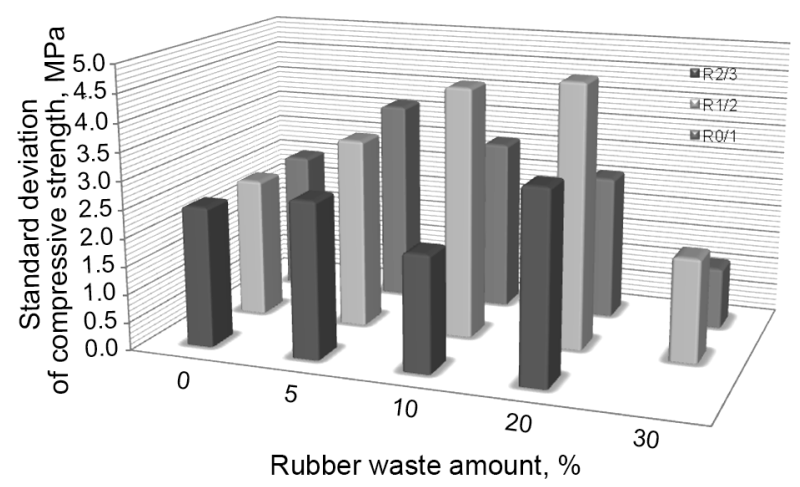

Fig. 3. Standard deviation of the compressive strength of concrete

2. When aggregates of higher density and strength (Mačiulaitis et al. 2009) are replaced with lower density and strength $\mathrm{CR}$, the compressive strength will decrease because the strength properties of concrete, which is composite material, depend on the strength of constituents (Eldin, Senouci 1994).

Observations revealed that the change in the compressive strength of concrete resulting from introduction of different amounts of CR can be mathematically approximated by exponential equation in a very precise manner. The approximation is presented in equations 1-3 (Eq. (1) is for CR 0/1 fr., (2) - for CR 1/2 fr., and (3) for CR 2/3 fr.):

$$
\begin{aligned}
& y=97.502 e^{-0.065 x} \\
& y=104.69 e^{-0.0594 x} \\
& y=104.88 e^{-0.0508 x}
\end{aligned}
$$

where: $\mathrm{x}-\mathrm{CR}$ amount in concrete, $\%$ by weight; $\mathrm{e}$ is the base of the natural logarithms.

The correlation factor (determination coefficient $\mathrm{R}^{2}$ ) in these exponential curves changes from 0.97 to 0.99 depending on the CR size fraction (varies from 0.91 to 0.97 in linear curve depending on $\mathrm{CR}$ fraction $\mathrm{R}^{2}$ ). The calculated correlation factor confirmed that the change in the compressive strength of concrete obtained from exponential equations shown in Fig. 4 was reliable. From mathematical functions presented in equations 1-3 we can reliably forecast the reduction in compressive strength with the addition of the certain amount of CR. For example, if CR is introduced at $1 \%$ of the total concrete volume, the compressive strength will drop by approx. $4 \%$ depending on the CR size fraction.

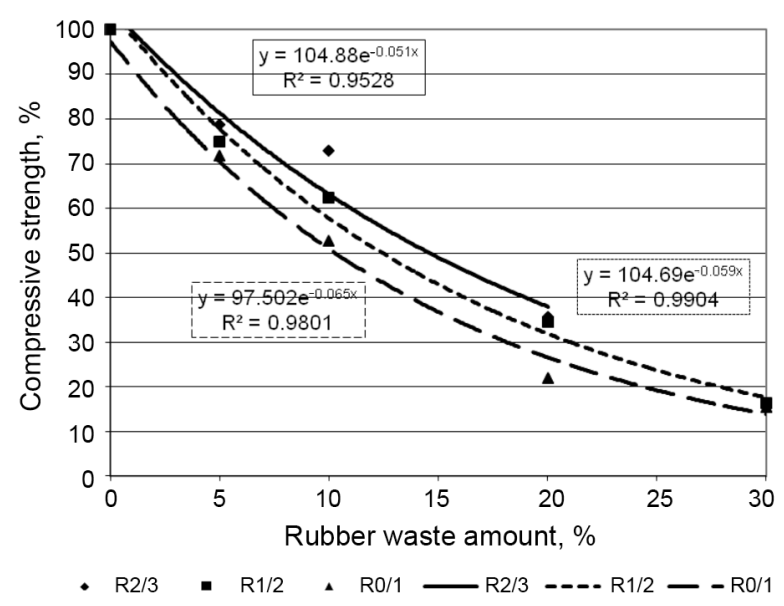

Fig. 4. Effect of CR amount and size fraction on the compressive strength of concrete

\subsection{The effect of crumbed rubber size fraction and amount on flexural strength of concrete}

Fig. 5 illustrates the flexural strength of concrete as a function of CR size fraction and CR amount. Here it may be seen that the flexural strength of concrete decreases depending on the amount of introduced CR. Fig. 5 shows that the average flexural strength of concrete, which is not modified with $\mathrm{CR}$, is $6.5 \mathrm{MPa}$ (standard deviation $\sigma=$ $0.22 \mathrm{MPa}$ ). When $\mathrm{CR}$ of the smallest size fraction is added, the flexural strength decreases from $4.1 \mathrm{MPa}(\sigma=$ $0.30 \mathrm{MPa}$ ) with $\mathrm{CR}$ added at $5 \%$ of the total aggregate amount, down to $1.8 \mathrm{MPa}(\sigma=0.21 \mathrm{MPa})$ with $\mathrm{CR}$ added at $30 \%$ of the total aggregate amount. In any case, the comparison of the flexural strength of control specimen with the flexural strength of specimens containing CR of bigger size fraction revealed similar tendencies. Fig. 5 shows that when fine aggregate is replaced with $1 / 2 \mathrm{fr}$. $\mathrm{CR}$ at $5 \%$ of the total aggregate amount, the flexural strength drops by $21 \%(5.1 \mathrm{MPa}, \sigma=0.24 \mathrm{MPa})$. With higher amount of $1 / 2$ fr. CR $(10,20,30 \%$ of the total aggregate amount) the flexural strength, in comparison with control specimens, decreased by $28 \%$ (4.7 $\mathrm{MPa}, \sigma=$ $0.22 \mathrm{MPa}$ ), $45 \%$ (3.60 $\mathrm{MPa}, \sigma=0.48 \mathrm{MPa}$ ) and $60 \%$ $(2.6 \mathrm{MPa} \sigma=0.11 \mathrm{MPa})$ respectively. The test results of specimens with the biggest size fraction (2/3) CR showed the decrease in compressive strength (compared to concrete not modified by $\mathrm{CR}$ ) by $18 \%$ (5.3 $\mathrm{MPa}, \sigma=$ $0.32 \mathrm{MPa}), 24 \%(5.0 \mathrm{MPa} \sigma=0.16 \mathrm{MPa})$ and by $39 \%$ $(3.9 \mathrm{MPa} \sigma=0.36 \mathrm{MPa})$ with the increase of CR amount by $5 \%, 10 \%$ and $20 \%$, respectively.

The spread of the test results was determined from the obtained flexural stresses (Fig. 6). The obtained standard deviation values ranged from $0.11 \mathrm{MPa}$ to $0.48 \mathrm{MPa}$. The tests showed that the standard deviation of the flexural strength had the highest value of $0.48 \mathrm{MPa}$ when CR of $1 / 2 \mathrm{fr}$. was added at $20 \%$ of the total aggre- 
gate amount, whereas specimens with CR of fr. 1/2 added at $30 \%$ of the total aggregate amount showed the least standard deviation of $0.11 \mathrm{MPa}$. It may be stated that the obtained results are reliable because the values of standard deviation of the flexural strength are low.

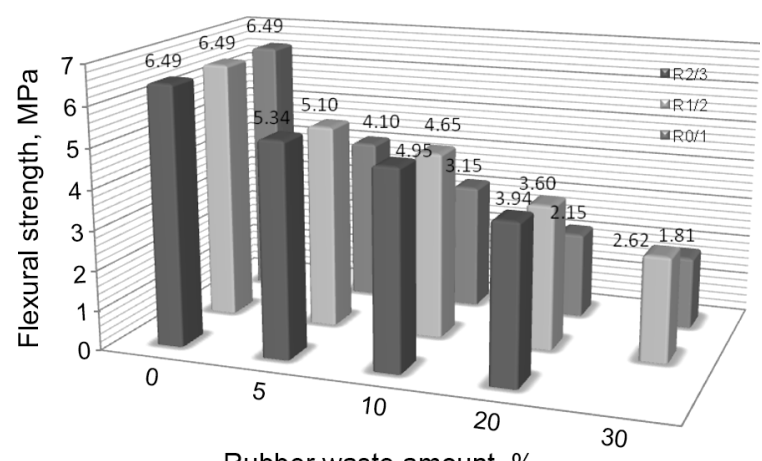

Fig. 5. The change in the flexural strength of concrete with CR of different amount and size fraction

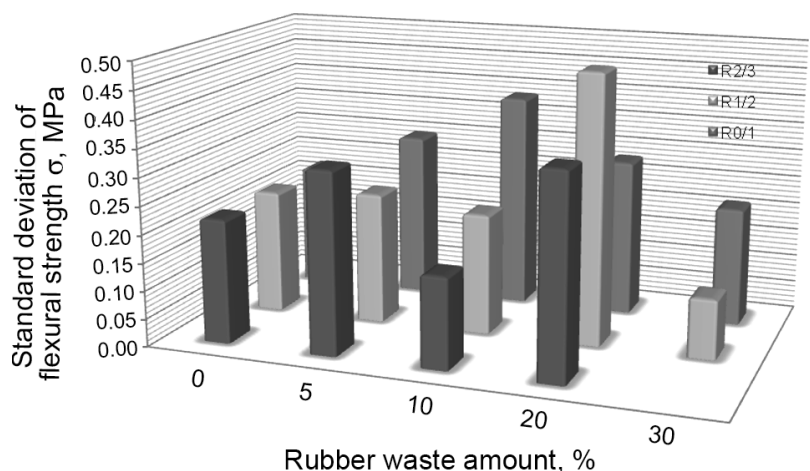

Fig. 6. Standard deviation of the flexural strength of concrete

Fig. 7 illustrates the change in the bending strength of concrete modified with different amounts of CR of different fraction size after 28 days of curing. The tests showed that there is exponential dependence in the decreasing of bending strength and different amount of crumb rubber. Exponential equations and $\mathrm{R}^{2}$ values are presented in Fig. 7. It was noted that the correlation factor of the obtained curve changed from 0.92 to 0.99 , subject to the CR size fraction. From the calculated $\mathrm{R}^{2}$ values, we see that the curves obtained are reliable to forecast the bending strength; therefore based on equations 4, 5 and 6 , we may forecast the bending strength of concrete modified by $0 / 1$ fr., $1 / 2$ fr and $2 / 3$ fr. CR when a certain amount of CR is introduced:

$$
\begin{aligned}
& y=83.198 e^{-0.0407 x} \\
& y=95.945 e^{-0.0286 x} \\
& y=96.87 e^{-0.0239 x}
\end{aligned}
$$

From the obtained exponential equations it may be easily forecasted that the bending strength of concrete will decrease by approx. $2.4 \%$ when CR is introduced at $1 \%$ of the total concrete volume. The relation of the decrease

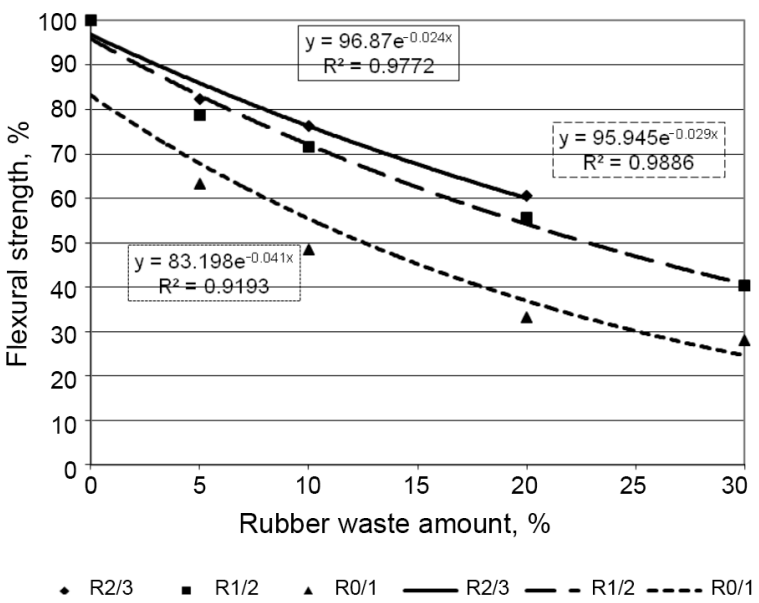

Fig. 7. Effect of CR amount and size fraction on the flexural strength of concrete

in bending strength and compressive strength of concretes modified with CR was also compared in the tests. The obtained results showed that introduction of CR at $30 \%$ of the total aggregate amount decreased the compressive strength of concrete by more than 6 times compared to non-modified concretes; whereas the bending strength of concretes modified with the same amount of CR decreased only by 3.6 times $(30 \%$ of $0 / 1 \mathrm{fr}$. rubber waste additive). Lower decrease in bending strength than in compressive strength in rubber modified concretes can be explained by better adhesion of cement stone to rubber particles than the adhesion of substituted sand with cement paste (Jakušovas, Daunys 2009; Daunys, Česnavičius 2009). Microscopy tests (Fig. 8a-d) showed that rubber particles up to $3 \mathrm{~mm}$ in size have more regular shape and smoother texture; the shape of smaller particles becomes irregular and their surface texture is rougher with numerous voids. More complicated surface texture of rubber particles gives better cohesion of cement matrix with rubber particles (Fig. 8e) (Eldin, Senouci 1993).

The surface of rubber particles is much rougher than the surface of sand, which is smooth and even (Fig. 8ad); therefore, the hardened cement paste has better adhesion to rubber particles. This is the reason why the bending strength decreases less in concretes modified with rubber waste additive.

\subsection{The effect of $C R$ size fraction and amount on splitting tensile strength of concrete}

Fig. 9 illustrates the splitting tensile strength of concrete as a function of CR size fraction and CR amount. Here it can be seen that the splitting tensile strength of concrete slightly increases when a small amount of CR is introduced; whereas with bigger amounts of additive, the splitting tensile strength decreases and continues decreasing with the increase in CR amount.

From Fig. 9 it may be seen that splitting tensile strength of non-modified concrete is around $3.48 \mathrm{MPa}$. This value increases up to $3.68 \mathrm{MPa}$ when the smallest size fraction $\mathrm{CR}$ is introduced at $5 \%$ of the total aggregate amount. Splitting tensile strength was also noted to increase in concretes with $\mathrm{CR}$ of bigger size fraction. We 
a)

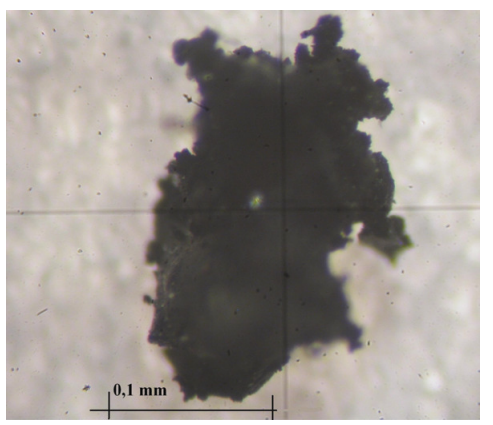

b)

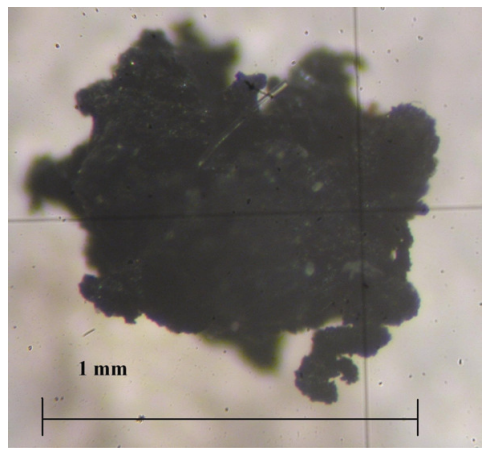

c)

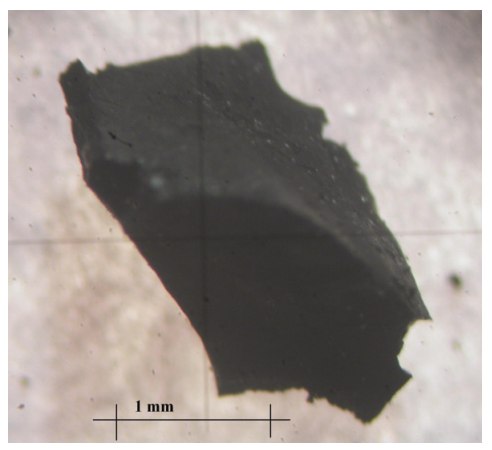

d)

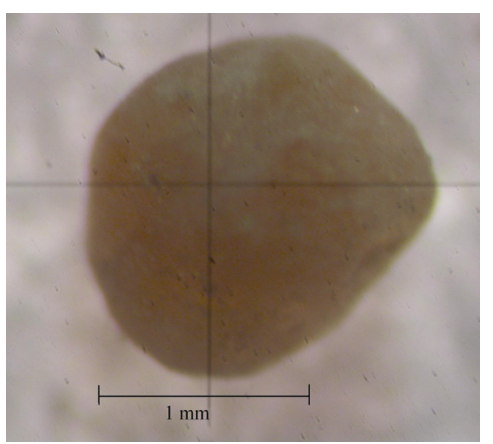

e)

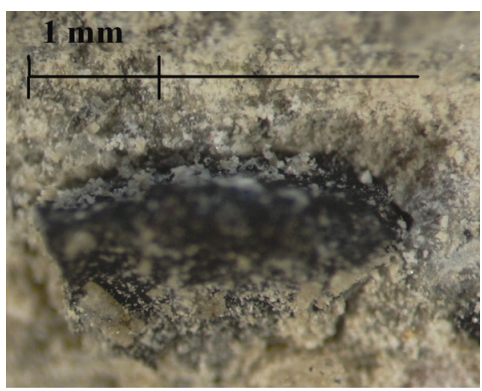

Fig. 8. Crumb rubber, particle size up to $0.5 \mathrm{~mm} \mathrm{(a);} \mathrm{Crumb}$ rubber, particle size up to $1.0 \mathrm{~mm}$ (b); Crumb rubber, particle size up to $3.0 \mathrm{~mm}$ (c); Sand particle (d); Contact zone of cement matrix and a rubber particle (e) determined that small amount of $1 / 2 \mathrm{fr}$. CR increased the tensile stress up to $3.51 \mathrm{MPa}$ and $2 / 3 \mathrm{fr}$. CR increased it up to $3.68 \mathrm{MPa}$. However, the splitting tensile strength of modified concrete compared to non-modified concrete started reducing when CR amount in concrete was increased (up to $30 \%$ of the total aggregate amount) irrespective of the additive size fraction. The tests revealed that with the highest CR amount (30\% of the total aggregate amount) used in testing the splitting tensile strength decreased more than twice compared to the specimens without CR (Fig. 9).

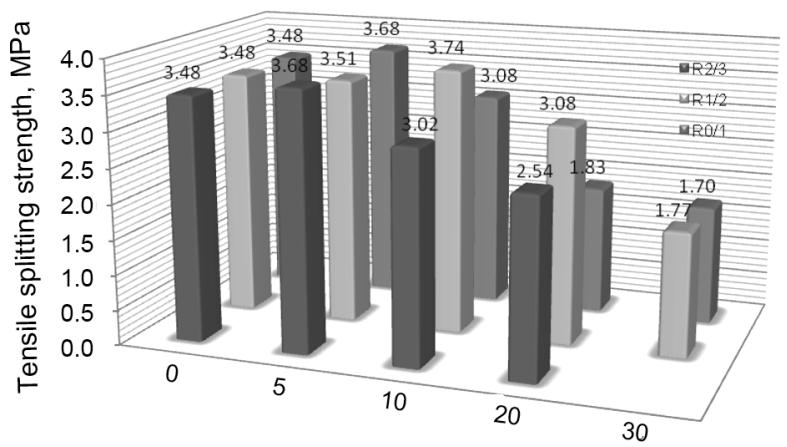

Rubber waste amount, \%

Fig. 9. The change in the splitting tensile strength of concrete

The obtained results showed that the splitting tensile strength of concrete modified with mechanically crumbed rubber of different size fractions decreased according to exponential equations (Fig. 10), the correlation factors of which changed in the interval of $0.73 \ldots 0.90$ depending on the size fraction of the additive.

Based on Eqs 7, 8 and 9 it was forecasted the splitting tensile strength of concrete modified by $0 / 1 \mathrm{fr}$., $1 / 2 \mathrm{fr}$ and $2 / 3 \mathrm{fr}$. CR when a certain amount of waste rubber is introduced:

$$
\begin{aligned}
& y=109.54 \mathrm{e}^{-0.029 x} \\
& y=114.98 \mathrm{e}^{-0.022 x} \\
& y=105.86 \mathrm{e}^{-0.018 x}
\end{aligned}
$$

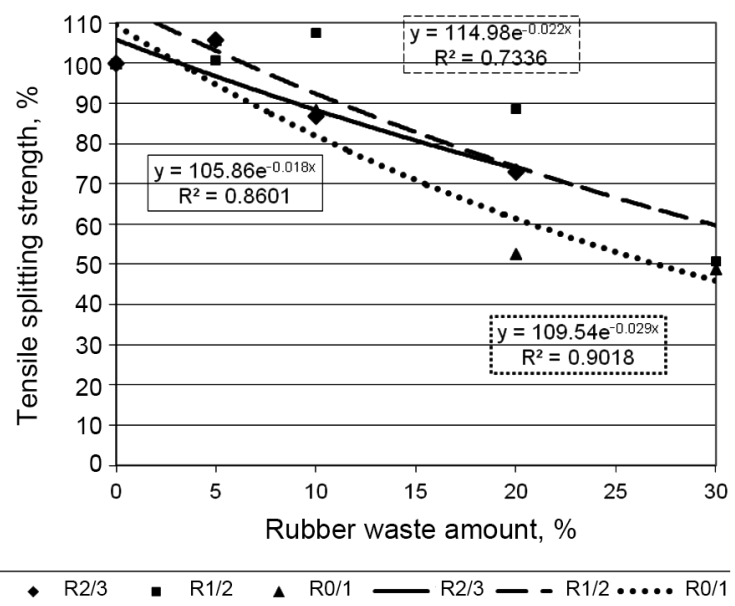

Fig. 10. Effect of $C R$ amount and size fraction on the splitting tensile strength of concrete 
To generalise the results of examined splitting tensile strength in concrete modified with CR, it may be noted that there is a slight increase in the splitting tensile strength of concrete when a small amount of CR is introduced. One of the possible reasons of this increase might be better adhesion of cement matrix with rubber particles compared to the adhesion of substituted sand with cement stone. Most probably, rubber particles due to their irregular shape and rough surface with numerous voids (Fig. 8 a-c) absorb the tensile stress more effectively and therefore the splitting tensile strength of such a conglomerate increases. With higher amount of $\mathrm{CR}$ in concrete, the splitting tensile strength decrease due to higher volume of entrained air and lower density (Skripkiūnas et al. 2010), which have a direct effect on the change in the tensile strength of concrete.

Vast amounts of used and non-biodegradable rubber tyres are accumulated in the world every year. Utilisation of such waste is still unresolved. The modification of cement concrete mixtures with crumbed rubber waste allows producing concrete that has specific properties (less density and thermal conditions, higher deformability and plasticity, better absorption of vibration and better sound insulation) and resolving the utilisation of rubber waste. It was found that crumbed rubber additives improve vibration damping properties (Skripkiūnas et al. 2009), although reduce strength characteristics of the concrete. Crumbed rubber additives may be used for higher impact-sound insulation in the floors of buildings or vibration damping in foundations and industrials floors, also for road building elements, such as road partitions, acoustic highways walls and bridge sidewalk blocks.

\section{Conclusions}

1. Due to low elastic modulus and high deformability of the rubber particles, the compressive, flexural and splitting tensile strengths of concrete decrease by respectively $84 \%, 72 \%$ and $51 \%$ when crumbed rubber amount is increased up to $30 \%$ of the total aggregate amount.

2. Tests of tensile splitting strength of concrete with crumbed rubber have shown that the addition of a small amount of this additive slightly increases the tensile splitting strength (7\%). Concrete with $30 \%$ of total aggregate amount of crumbed rubber has $61 \%$ lower decrease in bending strength than in compressive strength, when crumbed rubber additives are added to concrete. This can be explained by irregular shape and rough surface of rubber particles, which give better adhesion of rubber particles with cement stone than the adhesion of substituted sand with cement stone. With higher content of crumbed rubber additive in the concrete, the tensile splitting strength decreases due to the significant increase of entrained air content and lower density, which directly influence the change in the tensile splitting strength.

3. Changes in the strength (compressive, flexural and splitting tensile) of concrete with addition of a certain amount of crumbed rubber can be described by the calculated exponential mathematical functions.
4. Although concrete mixtures with crumbed rubber reduce strength characteristics of concrete, modification of cement concrete mixtures with crumbed rubber not only resulted in production of concrete that has specific properties (less density and thermal conditions, higher deformability and plasticity, better absorption of vibration and better sound insulation) but also resolution of rubber waste utilisation problem.

\section{References}

Albano, C.; Camacho, N.; Reyes, J.; Feliu, J. L.; Hernández, M. 2005. Influence of scrap rubber addition to Portland I concrete composites: destructive and non-destructive testing, Composite Structures 71(3-4): 439-446. http://dx.doi.org/10.1016/j.compstruct.2005.09.037

Barluenga, G.; Hernández-Olivares, F. 2004. SBR latex modified mortar rheology and mechanical behaviour, Cement and Concrete Research 34(3): 527-535.

http://dx.doi.org/10.1016/j.cemconres.2003.09.006

Batayneh, M. K.; Marie, I.; Asi, I. 2008. Promoting the use of crumb rubber concrete in developing countries, Waste Management 28(11): 2171-2176.

http://dx.doi.org/10.1016/j.wasman.2007.09.035

Benazzouk, A.; Douzane, O.; Mezerb, K.; Quéneudec, M. 2006. Physico-mechanical properties of aerated cement composites containing shredded rubber waste, Cement and Concrete Composites 28(7): 650-657.

http://dx.doi.org/10.1016/j.cemconcomp.2006.05.006

Bignozzi, M. C.; Sandrolini, F. 2006. Tyre rubber waste recycling in self-compacting concrete, Cement and Concrete Research 36(4): 735-739.

http://dx.doi.org/10.1016/j.cemconres.2005.12.011

Chou, L. H.; Lu, C.-K.; Chang, J.-R.; Lee, M. T. 2007. Use of waste rubber as concrete additive, Waste Management \& Research 25(1): 68-76.

http://dx.doi.org/10.1177/0734242X07067448

Colom, X.; Cañavate, J.; Carrillo, F.; Velasco, J. I.; Pagès, P.; Mujal, R.; Nogués, F. 2006. Structural and mechanical studies on modified reused tyres composites, European Polymer Journal 42(10): 2369-2378.

http://dx.doi.org/10.1016/j.eurpolymj.2006.06.005

Čygas, D.; Mučinis, D.; Sivilevičius, H.; Abukauskas, N. 2011. Dependence of the recycled asphalt mixture physical and mechanical properties on the grade and amount of rejuvenating bitumen, The Baltic Journal of Road and Bridge Engineering 6(2): 124-134.

http://dx.doi.org/10.3846/bjrbe.2011.17

Çelik, O. N.; Atiş, C. D. 2008. Compactibility of hot bituminous mixtures made with crumb rubber-modified binders, Construction and Building Materials 22(6): 1143-1147.

http://dx.doi.org/10.1016/j.conbuildmat.2007.02.005

Daunys, M.; Česnavičius, R. 2009. Low cycle stress strain curves and fatigue under tension-compression and torsion, Mechanika (6): 5-11.

Dong, R.; Li, J.; Wang, S. 2011. Laboratory evaluation of predevulcanized crumb rubber-modified asphalt as a binder in hot-mix asphalt, Journal of Materials in Civil Engineering ASCE 23(8): 1138-1144.

http://dx.doi.org/10.1061/(ASCE)MT.1943-5533.0000277

Eldin, N. N.; Senouci, A. B. 1993. Rubber-tyre particles as concrete aggregate, Journal of Materials in Civil Engineering 5(4): 478-496. http://dx.doi.org/10.1061/(ASCE) 0899-1561(1993)5:4(478) 
Eldin, N. N.; Senouci, A. B. 1994. Measurement and prediction of the strength of rubberized concrete, Cement and Concrete Composites ASCE 16(4): 287-298. http://dx.doi.org/10.1016/0958-9465(94)90041-8

Gaidučis, S.; Mačiulaitis, R.; Kaminskas, A. 2009. Eco-balance features and significance of hemihydrate phosphogypsum reprocessing into gypsum binding materials, Journal of Civil Engineering and Management 15(2): 205-213. http://dx.doi.org/10.3846/1392-3730.2009.15.205-213

Gesoğlu, M.; Güneyisi, E. 2007. Strength development and chloride penetration in rubberized concretes with and without silica fume, Materials and Structures 40(9): 953964. http://dx.doi.org/10.1617/s11527-007-9279-0

Gesoğlu, M.; Güneysi, E. 2011. Permeability properties of selfcompacting rubberized concrete, Construction and Building Materials 25(8): 3319-3326.

http://dx.doi.org/10.1016/j.conbuildmat.2011.03.021

Güneyisi, E.; Gesoğlu, M.; Özturan, T. 2004. Properties of rubberized concretes containing silica fume, Cement and Concrete Research 34(12): 2309-2317.

http://dx.doi.org/10.1016/j.cemconres.2004.04.005

Hernández-Olivares, F.; Barluenga, G. 2004. Fire performance of recycled rubber-filled high-strength concrete, Cement and Concrete Research 34(1): 109-117.

http://dx.doi.org/10.1016/S0008-8846(03)00253-9

Hernández-Olivares, F.; Barluenga, G.; Bollati, M.; Witoszek, B. 2002. Static and dynamic behaviour of recycled tyre rubber-filled concrete, Cement and Concrete Research 32(10): 1587-1596. http://dx.doi.org/10.1016/S00088846(02)00833-5

Jakušovas, A.; Daunys, M. 2009. Investigation of low cycle fatigue crack opening by finite element method, Mechanika (3): 13-17.

Karlsson, R.; Isacsson, U. 2003. Investigations on bitumen rejuvenator diffusion and structural stability, Journal of the Association of Asphalt Paving Technologists 72: 463501.

Khatib, Z. K.; Bayomy, F. M. 1999. Rubberized Portland cement concrete, Journal of Materials in Civil Engineering ASCE 11(3): 206-213. http://dx.doi.org/10.1061/(ASCE) 0899-1561(1999)11:3(206)

Lee, B. I.; Burnett, L.; Miller, T.; Postage, B.; Cuneo, J. 1993. Tyre rubber cement matrix composites, Journal. of Materials Science Letters 12(13): 967-968. http://dx.doi.org/10.1007/BF00420187

Lee, S.-J.; Akisetty, C. K.; Amirkhanian, S. N. 2008. The effect of crumb rubber modifier (CRM) on the performance properties of rubberized binders in HMA pavements, Construction on Building Materials 22(7): 1368-1376. http://dx.doi.org/10.1016/j.conbuildmat.2007.04.010

Li, G.; Stubblefield, M. A.; Garrick, G.; Eggers, J.; Abadie, C.; Huang, B. 2004. Development of waste tyre modified concrete, Cement and Concrete Research 34(12): 22832289. http://dx.doi.org/10.1016/j.cemconres.2004.04.013

Ling, T.-C. 2011. Prediction of density and compressive strength for rubberized concrete blocks, Construction and Building Materials 25(11): 4303-4306.

http://dx.doi.org/10.1016/j.conbuildmat.2011.04.074

Ling, T.-C. 2012. Effects of compaction method and rubber content on the properties of concrete paving blocks, Construction and Building Materials 28(1): 164-175.

Mačiulaitis, R.; Vaičienè, M.; Žurauskienè, R. 2009. The effect of concrete composition and aggregates properties on per- formance of concrete, Journal of Civil Engineering and Management 15(3): 317-324.

http://dx.doi.org/10.3846/1392-3730.2009.15.317-324

Mučinis, D.; Sivilevičius, H.; Oginskas, R. 2009. Factors determining the inhomogeneity of reclaimed asphalt pavement and estimation of its components content variation parameters, The Baltic Journal of Road and Bridge Engineering 4(2): 69-79. http://dx.doi.org/10.3846/1822427X.2009.4.69-79

Muhammad, B.; Ismail, M.; Bhutta, M. A. R.; Abdul-Majid, Z. 2012. Influence of non-hydrocarbon substances on the compressive strength of natural rubber latex-modified concrete, Construction and Building Materials 27(1): 241-246.

http://dx.doi.org/10.1016/j.conbuildmat.2011.07.054.

Najim, K. B.; Hall, M. R. 2012. Mechanical and dynamic properties of self-compacting crumb rubber modified concrete, Construction and Building Materials 27(1): 521-530. http://dx.doi.org/10.1016/j.conbuildmat.2011.07.013

Noureldin, A. S.; Wood, L. E. 1987. Rejuvenator diffusion in binder film for hot-mix recycled asphalt pavement, Transportation Research Record 1115: 51-61.

Papakonstantinou, C. G.; Tobolski, M. J. 2006. Use of waste tyre steel beads in Portland cement concrete, Cement and Concrete Research 36(9): 1686-1691. http://dx.doi.org/10.1016/j.cemconres.2006.05.015

Parant, E.; Rossi, P.; Boulay, C. 2007. Fatigue behavior of a multi-scale cement composite, Cement and Concrete Research 37(2): 264-269.

http://dx.doi.org/10.1016/j.cemconres.2006.04.006

Putman, B. J.; Amirkhanian, S. N. 2010. Characterization of the Interaction Effect of Crumb Rubber Modified Binders Using HP-GPC, Journal of Materials in Civil Engineering ASCE 22(2): 153-159. http://dx.doi.org/10.1061/(ASCE) 0899-1561(2010)22:2(153)

Rodezno, M. C.; Kaloush, K. E.; Way, G. B. 2005. Assessment of distress in conventional hot-mix asphalt and asphaltrubber overlays on portland cement concrete pavements. Using the new quide to mechanistic-empirical design of pavement structures, Transportation Research Record 1929: 20-27. http://dx.doi.org/10.3141/1929-03

Segre, N.; Joekes, I. 2000. Use of tyre rubber particles as addition to cement paste, Cement and Concrete Research 30(9): 1421-1425. http://dx.doi.org/10.1016/S0008-8846 (00)00373-2

Shirodkar, P.; Mehta, Y.; Nolan, A.; Sonpal, K.; Norton, A.; Tomlinson, C.; Dubois, E.; Sullivan, P.; Sauber, R. 2011. A study to determine the degree of partial blending of reclaimed asphalt pavement (RAP) binder for high RAP hot mix asphalt, Construction and Building Materials 25(1): $150-155$. http://dx.doi.org/10.1016/j.conbuildmat.2010.06.045

Siddique, R.; Naik, T. R. 2004. Properties of concrete containing scrap-tyre rubber - an overview, Waste Management 24(6): 563-569.

http://dx.doi.org/10.1016/j.wasman.2004.01.006

Sivilevičius, H. 2011. Modelling the interaction of transport system elements, Transport 26(1): 20-34. http://dx.doi.org/10.3846/16484142.2011.560366

Skripkiūnas, G.; Grinys, A.; Černius, B. 2007a. Deformation properties of concrete with rubber waste additives, Materials Science (Medžiagotyra) 13(3): 219-223.

Skripkiūnas, G.; Grinys, A.; Daukšys, M. 2007b. Using tyres rubber waste for modification of concrete properties, in 
The First International Conference on Sustainable Construction Materials and Technologies, 11-13 June, 2007, Coventry, UK, 85-90.

Skripkiūnas, G.; Grinys, A.; Miškinis, K. 2009. Damping properties of concrete with rubber waste additives, Materials Science (Medžiagotyra) 15(3): 266-272.

Skripkiūnas, G.; Grinys, A.; Janavičius, E. 2010. Porosity and durability of rubberized concrete, in The Second International Conference on Sustainable Construction Materials and Technologies, 28-30 June, Ancona, Italy, 1243-1253.

Stankevičius, V.; Skripkiūnas, G.; Grinys, A.; Miškinis, K. 2007. Acoustical characteristics and physical - mechanical properties of plaster with rubber waste additives, Materials Science (Medžiagotyra) 13(4): 304-309.

Sukontasukkul, P.; Tiamlon, K. 2012. Expansion under water and drying shrinkage of rubberized concrete mixed with crumb rubbex with different size, Construction and Building Materials 29: 520-526. http://dx.doi.org/10.1016/j.conbuildmat.2011.07.032

Taha, M. M. R; El-Dieb, A. S.; El-Wahab, M. A. A.; AbdelHameed, M. E. 2008. Mechanical, fracture, and microstructural investigations of rubber concrete, Journal of Materials in Civil Engineering ASCE 20(10): 640-649. http://dx.doi.org/10.1061/(ASCE)0899-1561(2008)20: 10(640)

Topçu, I. B.; Avcular, N. 1997. Collision behaviours of rubberized concrete, Cement and Concrete Research 27(12): 1893-1898. http://dx.doi.org/10.1016/S0008-8846(97)00204-4

Topçu, I. B.; Sarıdemir, M. 2008. Prediction of rubberized mortar properties using artificial neutral network and fuzzy logic, Journal of Materials Processing Technology 199(1-3): 108-118. http://dx.doi.org/10.1016/j.jmatprotec.2007.08.042

Venslovas, A.; Aleksandravičiūtè, D.; Idzelis, R. L. 2011. Experimental investigation of scrap-tyre crumb rubber application in noise-suppression structures, The Baltic Journal of Road and Bridge Engineering 6(2): 102-106. http://dx.doi.org/10.3846/bjrbe.2011.14
Vydra, Y.; Trtík, K.; Vodák, F. 2012. Size independent fracture energy of concrete, Construction and Building Materials 26(1): 357-361.

http://dx.doi.org/10.1016/j.conbuildmat.2011.06.034

Xiao, F.; Amirkhanian, S. N.; Juang, C. H. 2009. Prediction of fatigue life on rubberized asphalt concrete mixtures containing reclaimed asphalt pavement using artificial neural networks, Journal of Materials in Civil Engineering ASCE 21(6): 253-261. http://dx.doi.org/10.1061/(ASCE) 0899-1561(2009)21:6(253)

Xiao-qing, Z.; Can-hui, L.; Mei, L. 2009. Rheological property of bitumen modified by the mixture of the mechanochemically devulcanized tyre rubber powder and SBS, Journal of Materials in Civil Engineering ASCE 21(11): 699-705. http://dx.doi.org/10.1061/(ASCE)0899-1561(2009)21:11 (699)

Wang, R.; Wang, P.-M.; Li, X.-G. 2005. Physical and mechanical properties of styrene-butadiene rubber emulsion modified cement mortars, Cement and Concrete Research 35(5): 900-906. http://dx.doi.org/10.1016/j.cemconres.2004.07.012

Wong, S.-F.; Ting, S.-K. 2009. Use of recycled rubber tyres in normal and high-strength concretes, ACI Materials Journal 106(4): 325-332.

Wu, K.-R.; Zhang, D.; Song, J.-M. 2002. Properties of polymermodified cement mortar using pre-enveloping method, Cement and Concrete Research 32(3): 425-429. http://dx.doi.org/10.1016/S0008-8846(01)00697-4

Zhang, S. L.; Zhang, Z. X.; Pal, K.; Xin, Z. X.; Kim, J. K. 2010. Prediction of mechanical properties of waste polypropylene/waste ground rubber tire powder blends using artificial neural networks, Materials and Design 31: 36243629. http://dx.doi.org/10.1016/j.matdes.2010.02.039

Zhu, H.; Thong-On, N.; Zhang, X. 2002. Adding crumb rubber into exterior wall materials, Waste Management \& Research 20(5): 407-413. http://dx.doi.org/10.1177/0734242X0202000504

Audrius GRINYS. Doctor of Technological Sciences, Lecturer of the Department of Building Materials at Kaunas University of Technology. Chief Technologist at JSC Betono Centras. Research interests: ready mix concrete, concrete deformability, concrete strength and utilization of waste materials.

Henrikas SIVILEVIČIUS. Dr Habil, Prof. of the Department of Transport Technological Equipment at Vilnius Gediminas Technical University. Doctor (1984), Doctor Habil (2003). Publications: more than 170 scientific papers. Research interests: flexible pavement life cycle, hot mix asphalt mixture production technology, application of statistical and quality control methods, recycling asphalt pavement technologies and design, decision-making and experst systems theory.

Mindaugas DAUKŠYS. Doctor of Technological Sciences, Assoc. Prof. of the Department of Civil Engineering Technologies at Kaunas University of Technology (KTU). Research interests: concrete mixtures technology, rheology of the cement pastes and concrete mixtures, concrete admixtures, nanotechnology in the concrete technology. 